\title{
PLANTS
}

\section{ARNICAS IN SASKATCHEWAN}

VERNON L. HARMS, \# 212-115 Keevil Crescent, Saskatoon, SK S7N 4P2

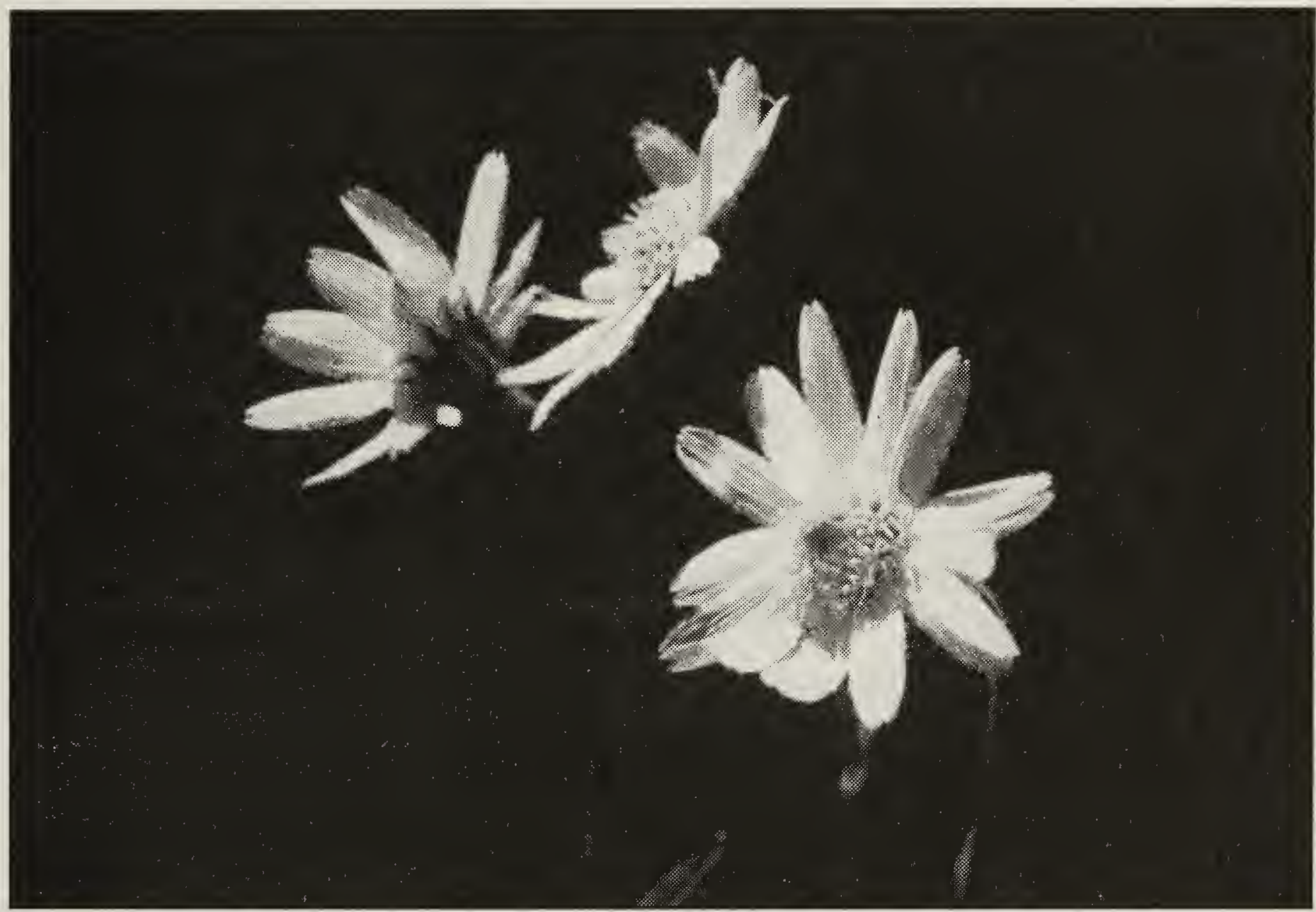

Narrow-leaved (Alpine) Arnica

Blake Maybank

Unlike many other yellow-headed composites, the arnicas (Arnica species) are not a particularly common group in our province's natural flora. But, when we encounter them in prairies and woodlands, their large, bright yellow flowers attract the eye. Some wildflower enthusiasts may be more familiar with arnicas in the Rocky Mountains where their frequency is greater, although six native Arnica species are known in Saskatchewan. These showy wild flowers are mostly about a half-metre tall, with flowering heads solitary or few, yellowrayed, and relatively large, mostly over $5 \mathrm{~cm}$ broad.

Like all wild species, arnicas play an integral role in the functioning of native ecosystems and for us, they beautify natural landscapes. Medicinal properties have also been ascribed to them. Tincture of arnica, prepared from all parts of the plant - flowers, roots and leaves - is reputed to heal or soothe skin irritations, bruises, sprains, and even arthritic pains when applied superficially to the skin. Such preparations are available at many health food stores.

The origin of the Latin name Arnica is rather ambiguous. Some suggest that it represents a corruption of Ptarmica, in reference to the well known European plant, Achillea ptarmica. Others believe the name originated from the Greek word arnakis meaning "lamb's skin", a possible allusion to the woolly hairiness of leaves and bracts in some species. The common name most often used for our Arnica species is simply 
Figure 1. Habit sketches of Saskatchewan Arnica species.

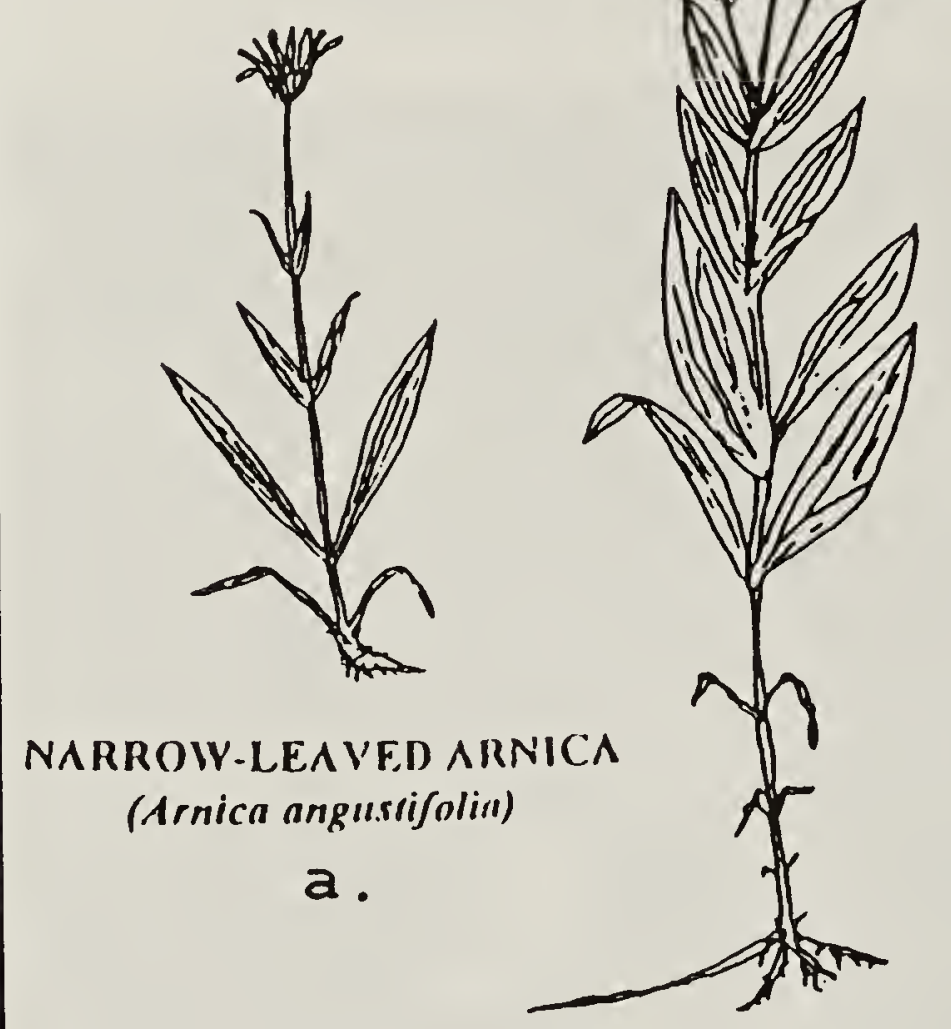

LEAFY ARNICA

(Arnicn chamissonis ssp. foliosa)

b.

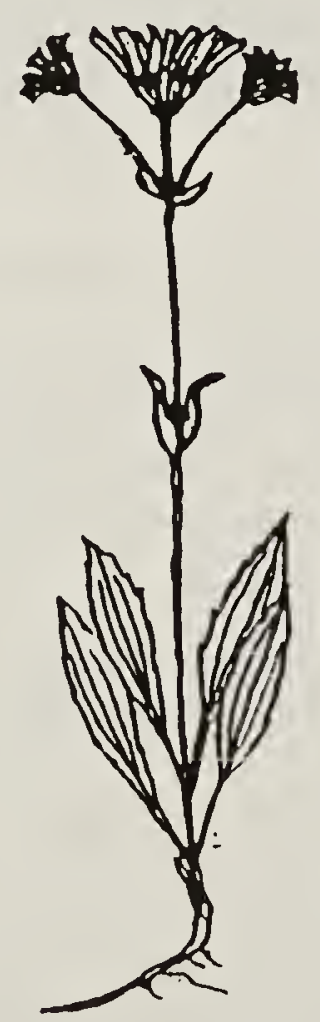

SPEAR-LEAVED ARNICA

(Arnica lonchophylla)

d.

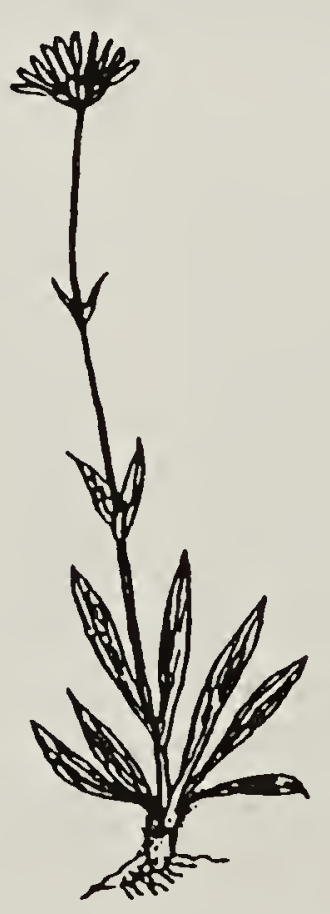

SUINING ARNICA (Arnica fulgens)

e.

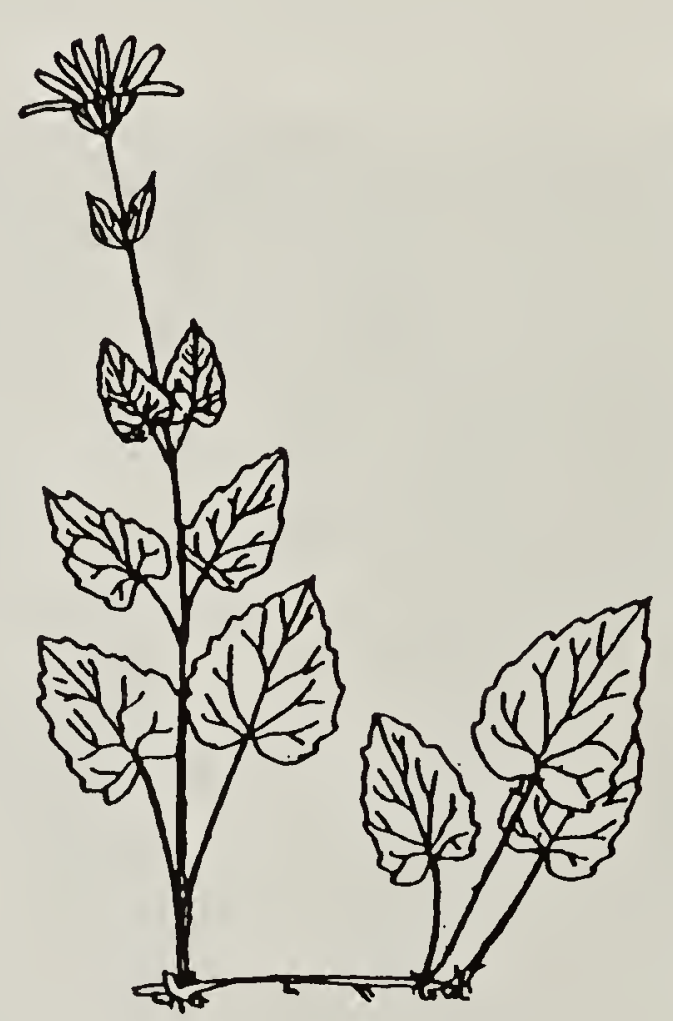

HEART-LEAVED ARNICA (Arnica cordifolia)

C.

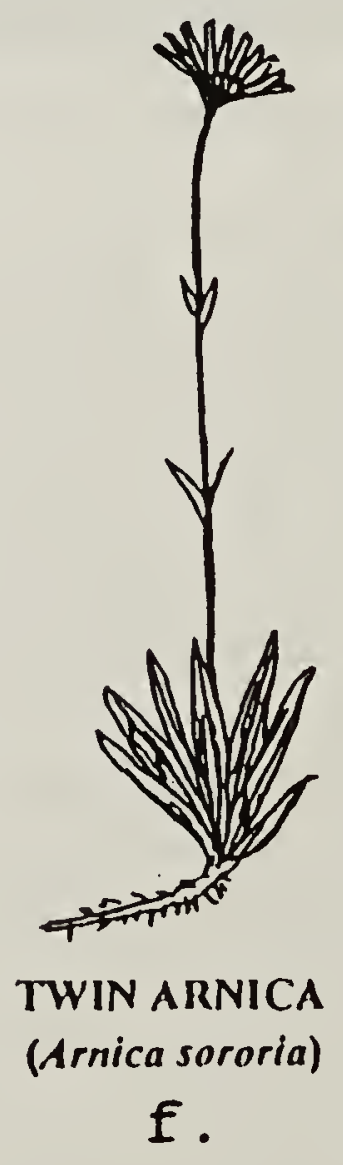


Maps 1-6. Saskatchewan Distributions of Arnica Species
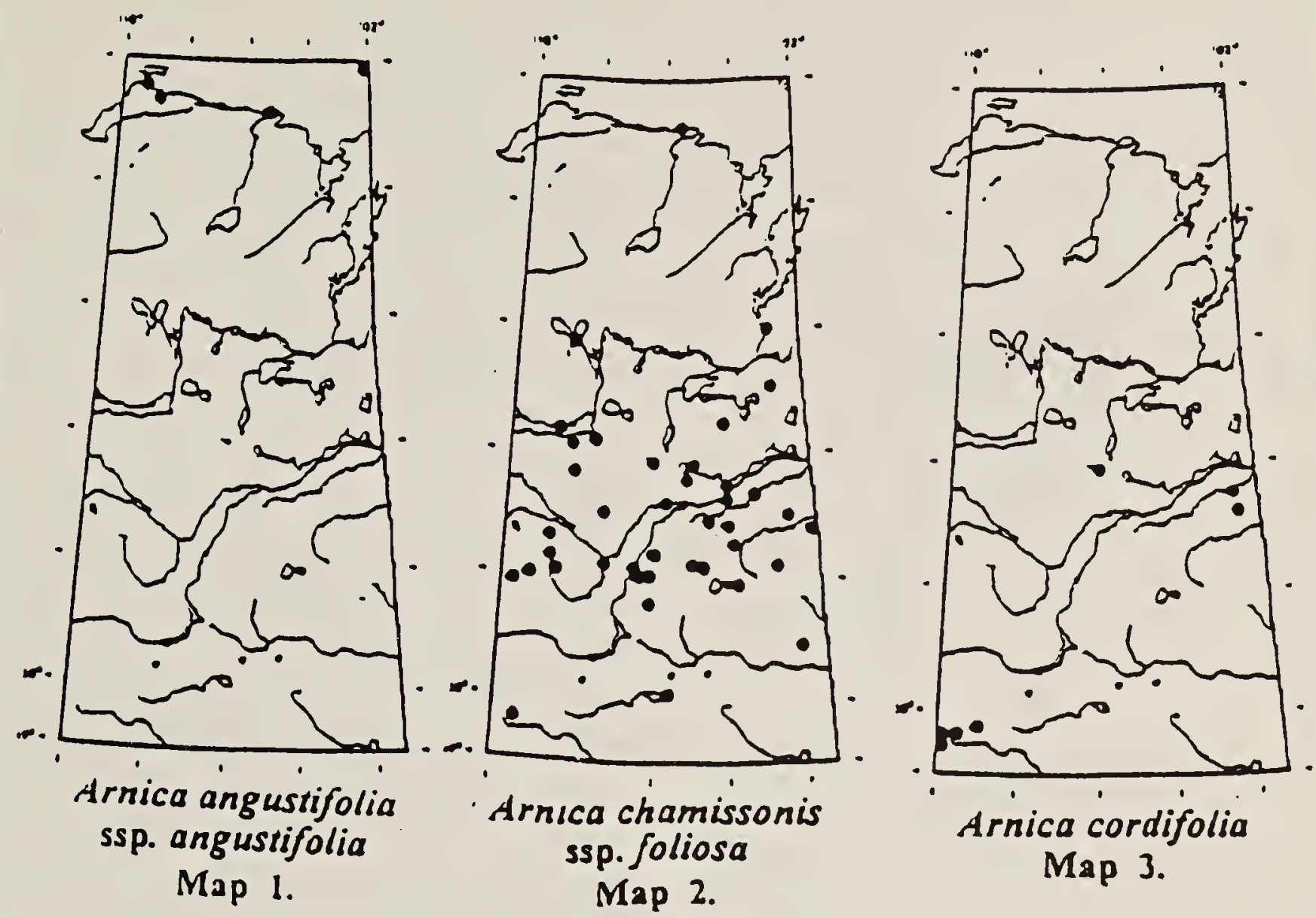

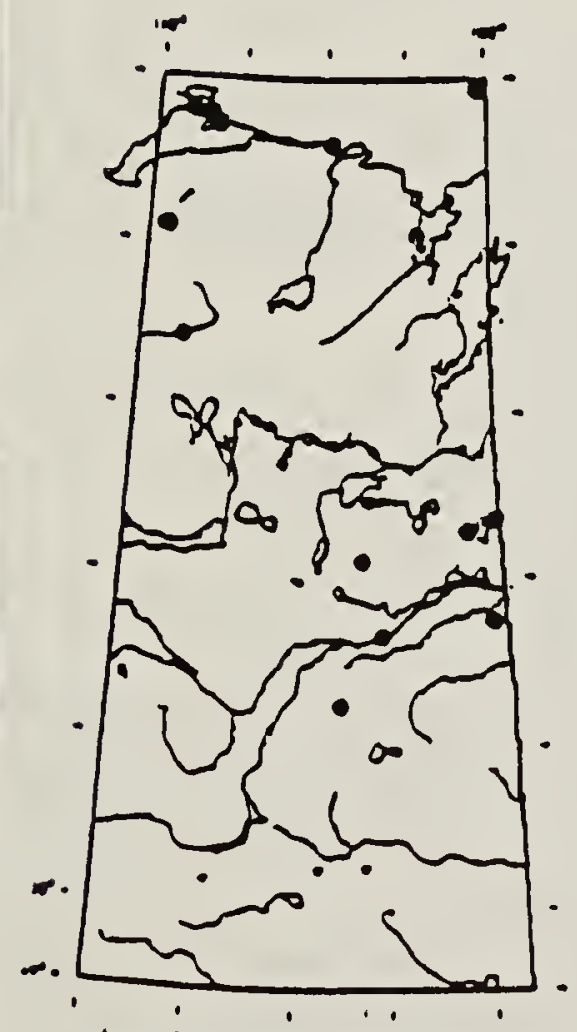

Arnica lonchophylla ssp. lonchophylla Map 4.
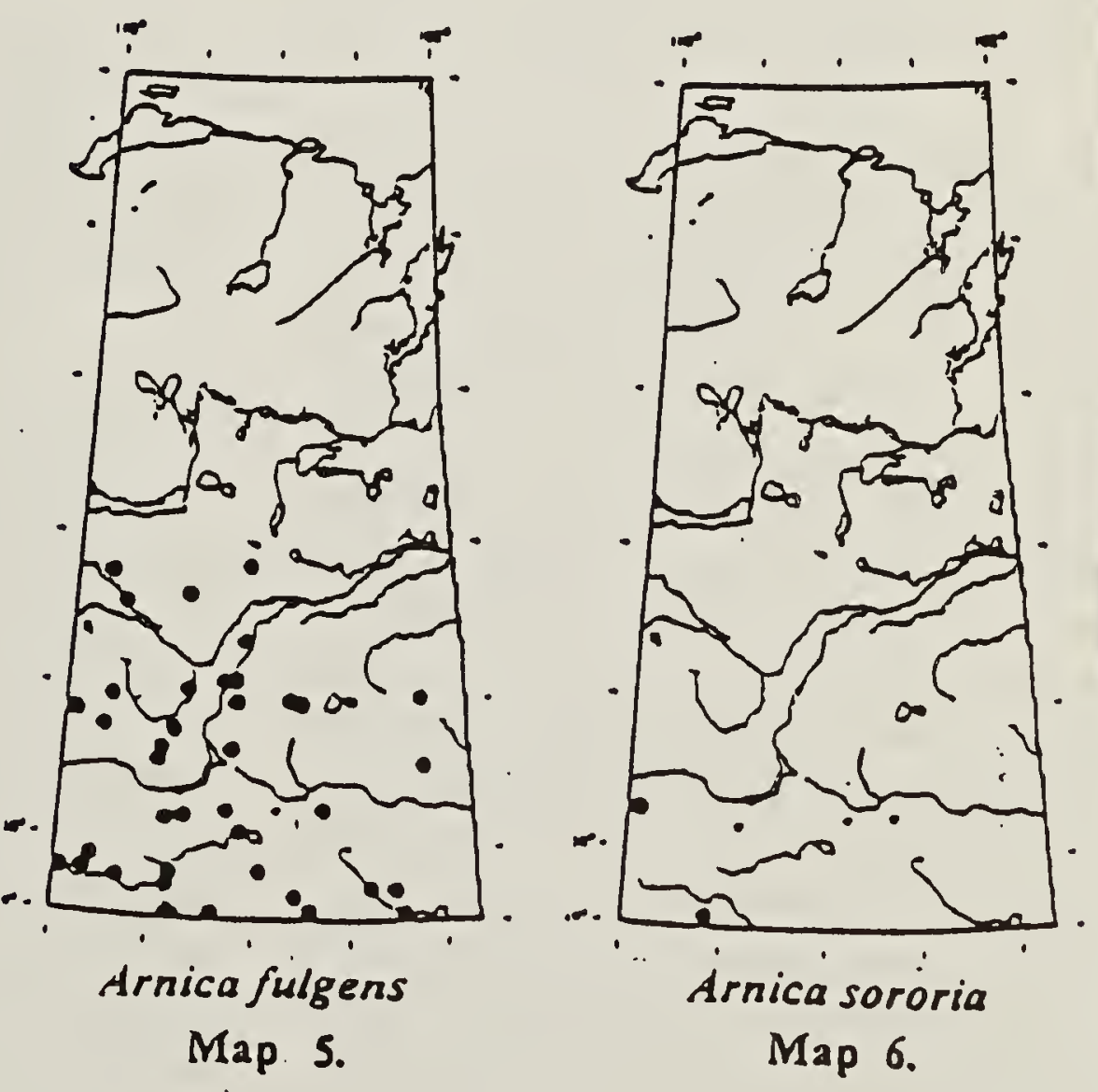
the Latin genus name itself, "arnica". Such vernacular use of scientific names is hardly unusual - other genera named in this way include the native plants Aster, Anemone, Phlox, and Corydalis, and ornamentals such as Zinnia, Coleus, Dahlia, Amaryllis, Hibiscus, Gladiolus, Chrysanthemum and Iris. The common name "leopard-bane" has also been used for Arnica species, although rarely in Saskatchewan and Canada. The origin of this name is unknown to me, but suggests an interesting story.

The genus Arnica consists of about 32 species distributed in temperate and arctic regions of the northern hemisphere, with 25 native in North America, 17 of which occur in Canada, and six in Saskatchewan. Two of Saskatchewan's Arnica species are provincially rare, and two others are uncommon and were once listed as rare., 2 The remaining two species are more common in the province, but not abundant. Our six Arnica species are illustrated in Figure 1, and their recorded Saskatchewan distributions are shown in Maps 1-6.

Saskatchewan Arnica species are not too difficult to identify, although knowledge of their basic floral and vegetative structures, and careful observations of some key diagnostic traits, are required (Figure 2). Arnica species are members of the large aster family, Asteraceae (or Compositae) and, like other members of that prominent family, have their small true flowers (florets) closely grouped on a common platform (receptacle) into aggregates called "heads". Each head is surrounded by an involucre consisting of series of small leafy structures, the involucral bracts. The clusters of heads on plants are called "inflorescences". An Arnica flowering head has the appearance of a single, large flower, with the symmetrical, tubular inner florets (disk florets) massed in the central part (disk) of the head, and the asymmetrical, marginal florets modified to form the strap-shaped "rays" (ligules) that radiate out from the periphery of the head, like the petals of other flowers. The individual disk florets have a corolla tube of five fused petals enclosing a tube of five fused anthers, both arising from the top of the ovary. Also borne from the ovary summit is the style with two pollen-receptive stigmas that extend through the anther tube to protrude at maturity. After insect pollination and fertilization of the flowers, the ovary matures into a 1-seeded fruit, called an achene, that is dispersed intact like a seed. A crown of bristly hairs, called the pappus, arises as a circle at the achene's summit serving as a parachute to aid in wind dispersal. Arnica plants are perennial herbaceous forbs, with solitary unbranched stems arising from rhizomes, bearing leaves that are both basal and in opposite pairs along the stem. The leaves are simple (not divided into segments) with margins that are either toothed or untoothed (entire), but not lobed. The different types and density of the hairiness on stems, leaves and involucres may be diagnostically helpful in distinguishing Arnica species.

The dichotomous taxonomic key on page 55 may be used to distinguish the Saskatchewan species. Each species is described below, listed in alphabetical order by species name.

\section{Arnica angustifolia Vahl. - NARROW- LEAVED or ALPINE ARNICA.}

[Synonyms: A. alpina (L.) Olin var. attenuata (Greene) Edig.\& Barkl; $A$. alpina var. angustifolia (Vahl) Fern.].

This is the smallest of our arnicas and also one of the rarest. It is found in small numbers on open, gravelly or rocky shores, slopes, cliffs and ledges, in far northern Saskatchewan, north of latitude $59^{\circ} \mathrm{N}$. Because of apparently low frequencies and small local populations, Narrow-leaved Arnica is considered an endangered species in the province. ${ }^{2}$ The species epithet, angustifolia, combining the Latin adjectives angustus meaning "narrow" with folius meaning "leaved", refers to the narrow leaves of the species. (See Figure 1-a, and Map 1). 
Figure 2. Some characteristic features of Arnica flowers and heads.

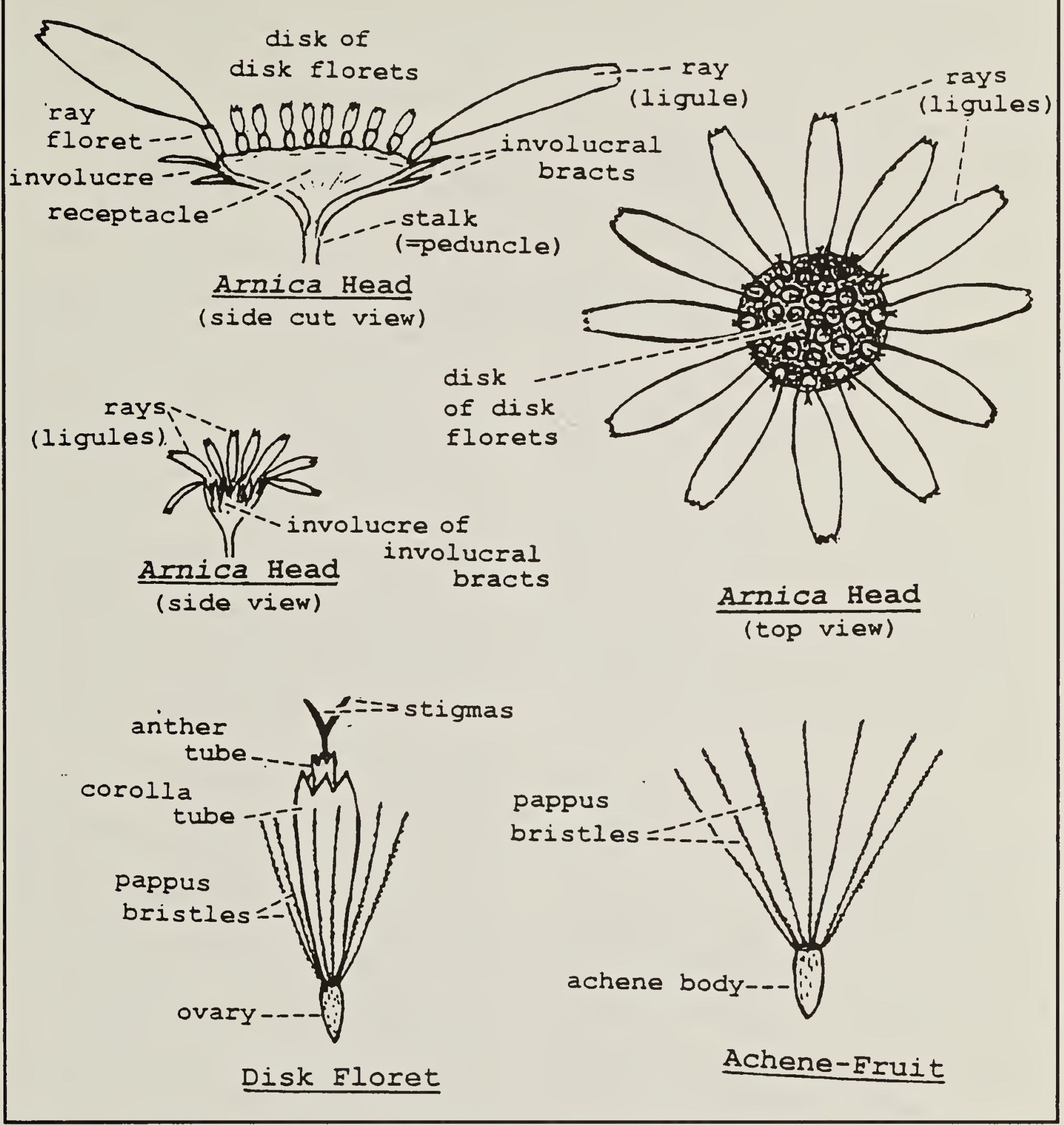

Arnica chamissonis Less. ssp. foliosa (Nutt.) Mag. - LEAFY ARNICA.

This is the tallest, leafiest, and most widespread of our provincial arnicas, with records extending from the Cypress Hills and Old Wives Lake in southern Saskatchewan, northward to Black Lake at about latitude $59^{\circ} \mathrm{N}$, and from west to east across the province. It is most frequent in the aspen parkland and transitional boreal forest regions, less frequent in the true grassland and southern boreal regions, and almost absent in the northern boreal forest. Except for the apparently isolated Black Lake site, all Saskatchewan records are from south of latitude $56^{\circ} \mathrm{N}$, but it is recorded in northeasternmost Alberta and adjacent N.W.T. It grows mainly in moist grassland depressions, shore meadows, open woods and clearings. The species epithet chamissonis was given in honor of the German botanist, Ludolf Adelbert von Chamisso, who collected and described plants from western North America in 1816. The subspecific epithet foliosa is Latin meaning "leafy", a reference to the leafiness of this species. (See Figure 1-b, and Map 2). 
Arnica cordifolia Hook. - HEARTLEAVED ARNICA.

This is probably our most recognizable Arnica species, with its basal and lower leafblades broad, heart-shaped, coarsely toothed, and long-stalked. Although this species is abundant in the Rocky Mountains, it is relatively uncommon in Saskatchewan. Here it is most frequently encountered in the Cypress Hills, which is not surprising since this region supports a Rocky Mountain flora. Oddly, it is also found at two other well separated areas in the province - near Waskesiu Lake, and in the Pasquia Hills. It grows mainly on rather moist sites in open pine woods (in the Cypress Hills under Lodgepole Pine, Pinus cordata var. latifolia, and elsewhere under Jack Pine, $P$. banksiana), but it also occurs in other open deciduous or mixed woods. The species epithet cordifolia, combining the Latin adjectives cordatus meaning "heart-shaped" with folius meaning "leaved", is descriptive of the heart-shaped leaves. (See Figure 1-c, and Map 3).

\section{Arnica fulgens Pursh - SHINING or ORANGE ARNICA.}

This grassland species is our most common arnica and the one most frequently encountered in the prairie region, although it is less widespread overall in the province than Leafy Arnica. It is most characteristic of fairly moist places in grasslands, meadows and open shores, occurring throughout southern Saskatchewan in suitable habitats, extending northward to near latitude $54^{\circ} \mathrm{N}$. The species epithet, fulgens, is a Latin word meaning "shining" or "bright-colored", and is a probable reference to the brightly coloured flowering heads of this species. (See Figure 1-e, and Map 5).

\section{Arnica lonchophylla Greene - SPEAR- LEAVED ARNICA.}

This uncommon boreal species is known from various widely spaced localities in northern Saskatchewan, ranging from near the northern border (latitude $60^{\circ} \mathrm{N}$ ), southward to about latitude $53^{\circ} \mathrm{N}$. It mainly grows in relatively dry, open mixed and coniferous woods, and often on limestone substrates or gravelly eskers. The specific epithet is an apparent reference to its large, spear-shaped, basal and lower leaves. (See Figure 1-d, and Map 4).

\section{Arnica sororia Greene - TWIN ARNICA.}

Based on the only two records verified for southwestern Saskatchewan, this species appears the rarest of our arnicas. It has been known for over a decade from a site $13 \mathrm{~km}$ se of Climax. Recently, during the 2001 summer, a second provincial collection was made about $8 \mathrm{~km} \mathrm{~s}$-se of Burstall (Anna Leighton, pers. comm.). I personally verified the specimens. Other collections from southwestern Saskatchewan once determined as this species have been revised to $A$. fulgens. With its apparent infrequency and low population numbers, Twin Arnica, is considered an endangered species in the province. ${ }^{2}$ This arnica is quite similar in general appearance to Shining Arnica and could readily be mistaken for that species by naturalists unaware of the distinguishing criteria. The species epithet sororia is based on the Latin soror meaning "sister". But why either this epithet, or the common name "Twin Arnica", should have been applied to A. sororia is unclear to me. Possibly it was because of its close similarity - i.e. as a twin or sister species - to the more common Shining Arnica (See Figure 1-f, and Map 6).

1. HARMS, V.L., P.A. RYAN, AND J.A. HARALDSON. 1992. The Rare and Endangered Native Vascular Plants of Saskatchewan: Development of the Saskatchewan Rare Plants Database and Summary Sheets of the Candidate Rare Species. Report for the Saskatchewan Natural History Society. The W.P. Fraser Herbarium, University of Saskatchewan, Saskatoon, SK. 1144 pp.

2. HARMS, VERNON L. 2000. Rare Native Vascular Plants of Saskatchewan. The W.P. Fraser Herbarium, University of Saskatchewan, Saskatoon, SK. $40 \mathrm{pp}$. 


\section{Taxonomic Key to the Arnica Species in SK}

1a. Blades of the larger basal and lower stem leaves coarsely toothed, less than twice as long as broad, with heart-shaped bases, borne on leaf-stalks distinctly longer than the blades.

A. cordifolia.

1b. Larger leaf-blades with smaller teeth or entire (not toothed), narrower and lance-shaped, over 3 times longer than broad, tapered or rounded but not heart-shaped at base; stalks of basal and lower leaves as long as or shorter than the blades. (to 2 ).

2a. Stem-leaves in 5-8 pairs below the inflorescence, not markedly reduced upwards along stem; involucral bracts tipped with tufts of long hairs.

A. chamissonis.

2b. Stem-leaves in only 2-4 pairs below the inflorescence; tips of involucral bracts lacking tufts of long hairs (although sometimes with short hairs).

3a. Lower leaves with long stalks to about as long as the blades; leaf-blade margins with small distinct teeth quite widely but regularly spaced and nearly opposite; heads usually more than 1 , mostly $3-5$.................. lonchophylla.

3 b. Lower leaves sessile (stalkless) or stalks short, much shorter than the blades; leaf-blade margins either entire (not toothed) or irregularly small-toothed; heads usually solitary (rarely 2-3). (to 4).

4a. Involucres densely covered with white-woolly hairs, but only obscurely glandular; stems and leaves hairy but scarcely glandular; stem-leaves in 2-3 pairs below the inflorescence; plants shorter than $3 \mathrm{dm}$, of far northern Saskatchewan.

\section{A. angustifolia.}

4b. Involucres hairy and distinctly glandular, but not densely woolly; stems and leaves hairy and also strongly glandular, especially upwards; stem-leaves in 34 pairs below the inflorescence; plants 2-6 dm tall, of southern Saskatchewan. (to 5).

5a. Old leaf-bases at stem base with conspicuous, dense tufts of long, tawnybrown, woolly hairs; disk-corollas with non-glandular as well as glandular hairs; pappus-hairs on achene-fruits white to straw-colored; mid-stem leaves spear-shaped, about $1 \mathrm{~cm}$ wide; stems stoutish, from short thick rhizomes. A. fulgens.

5b. Old leaf-bases at stem base of lacking tufts of tawny-brown woolly hairs (hairs white if some present); disk-corollas with only glandular hairs; pappus-hairs always white; mid-stem leaves more narrowly spear-shaped, less than $1 \mathrm{~cm}$ wide; stems more slender, from longer and thinner rhizomes. .... A. sororia. 